\title{
STUDI KEBIJAKAN TENTANG KURIKULUM PENGEMBANGAN MUATAN LOKAL
}

\author{
1 Dewi Zainul Alfi, 2 M. Yunus Abu Bakar \\ ${ }^{1}$ Universitas Hasyim Asy'ari Tebuireng Jombang, ${ }^{2}$ Universitas Hasyim Asy'ari \\ Tebuireng Jombang \\ 1 dewizainulalfi@gmail.com, ${ }^{2}$ elyunusy@gmail.com
}

\begin{abstract}
Local content is study material in educational units which consists of content and learning processes about potential and local uniqueness. The application of a local content curriculum can provide knowledge, skills, formation of student attitudes, insight into environmental conditions and community needs. Local content development is carried out in two ways, namely long-term and short-term development so that students can improve their skills. Then, it is expected to be able to help theirself, family, community and contribute to country and nation development. This research is a literature study so that the method of analyzing data is by reviewing and collecting information from various reference books and scientific articles. Literature references are used as material in studying and adding conceptual insights related to the local content development curriculum.
\end{abstract}

\section{ABSTRAK \\ Muatan lokal adalah bahan kajian atau mata pelajaran pada satuan pendidikan yang berisi muatan dan proses pembelajaran tentang potensi dan keunikan lokal. Penerapan kurikulum muatan lokal dapat memberikan bekal pengetahuan, keterampilan, pembentukan sikap dan perilaku siswa, berupa wawasan tentang keadaan lingkungan dan kebutuhan masyarakat. Pengembangan Muatan Lokal dilakukan dengan dua arah pengembangan dalam muatan lokal, yaitu Pengembangan untuk jangka jauh agar para siswa dapat melatih keahlian dan keterampilan yang sesuai dengan harapan yang nantinya dapat membantu dirinya, keluarga, masyarakat dan akhirnya membantu pembangunan nusa dan bangsanya. Studi ini merupakan studi literatur sehingga metode dalam menganalisis data dengan meninjau dan mengumpulkan informasi dari berbagai referensi baik buku, artikel ilmiah yang digunakan sebagai bahan dalam mempelajari dan menambah wawasan secara konseptual yang berhubungan dengan studi kebijakan tentang kurikulum pengembangan muatan lokal.}

\section{ARTICLE HISTORY}

Received 26 Januari 2021

Revised 18 Maret 2021

Accepted 20 Maret 2021

\section{KEYWORDS}

Development, Curriculum, Local Content 
Dewi Zainul Alfi dan M. Yunus Abu Bakar, Studi Kebijakan tentang Kurikulum

\section{PENDAHULUAN}

Kehidupan manusia tidak pernah terlepas dari lingkungan dimana dia hidup, mencakup lingkungan sosial maupun lingkungan alam. Manusia mempunyai ketergantungan akan semua lingkungan tersebut, maka dari itu manusia harus bisa mengelola lingkungannya dengan baik dan benar. Begitu pula dengan proses pendidikan, baiknya juga mengajarkan manusia dalam memahami lingkungannya. Pembelajaran berlangsung dengan menyesuaikan lingkungan yang ada. Karena mau tidak mau pasti kita juga masih menempati lingkungan yang sama dalam kehidupan sehari-hari meskipun tidak menutup kemungkinan kita akan hidup di luar lingkungan asal. Maka dari itu setiap pengembangan kurikulum harus senantiasa mempelajari situasi dan kondisi masyarakat, agar apa yang dipelajari di sekolah sesuai dengan apa yang dialami dalam lingkungan sehari-hari.

Berdasarkan uraian tersebut, maka muncullah kurikulum muatan lokal di sekolah. Karena Muatan lokal merupakan bahan kajian atau mata pelajaran pada satuan pendidikan yang berisi muatan dan proses pembelajaran tentang potensi dan keunikan lokal yang dimaksudkan untuk membentuk pemahaman peserta didik terhadap keunggulan dan kearifan di daerah tempat tinggalnya. ${ }^{1}$

Dengan adanya kebijakan ini diharapkan dapat menjawab kebutuhan dunia pendidikan di Indonesia dalam menanamkan kemampuan masyarakatnya untuk mengenal terlebih dapat mengelola lingkungannya. Dalam Pasal 77 N Peraturan Pemerintah Nomor 32 Tahun 2013 tentang Perubahan Atas Peraturan Pemerintah Nomor 19 Tahun 2005 tentang Standar Nasional dinyatakan bahwa: (1) Muatan lokal untuk setiap satuan pendidikan berisi muatan dan proses pembelajaran tentang potensi dan keunikan lokal; (2)

\footnotetext{
1 Permendikbud, "Peraturan Menteri Pendidikan dan Kebudayaan Nomor 79 Tahun 2014 Tentang Muatan Lokal Kurikulum 2013" (2014): 2, Https://Drive.Google.Com/File/D/0BZ3dlpawpaqbk9ftthiywm3bjq/View.
} 
Muatan lokal dikembangkan dan dilaaksanakan pada setiap satuan pendidikan. ${ }^{2}$ Dengan munculnya peraturan ini maka setiap satuan pendidikan harus memberikan muatan lokal kepada setiap peserta didik.

Dari berbagai uraian di atas maka dirasa penting bagi penulis untuk membahas terkait studi kebijakan tentang pengembangan kurikulum muatan local yang sudah terlaksana selama ini. Penulis berharap bisa bermanfaat bagi pembaca dalam mempelajari apapun terkait kurikulum muatan lokal.

Oleh karena itu, penulis ingin menjelaskan dalam makalah ini mengenai kurikulum muatan lokal, proses pelaksanaan kurikulum muatan lokal dan pengembangan kurikulum muatan lokal yang sudah terlaksana pada satuan pendidikan.

\section{METODE PENELITIAN}

Metode merupakan alat yang digunakan untuk memecahkan permasalahan penelitian, di dalamnya juga terdapat metode analisa. ${ }^{3}$ Penelitian ini menggunakan pendekatan kualitatif dengan jenis deskriptif.

\section{HASIL DAN PEMBAHASAN}

\section{Definisi Kurikulum Muatan Lokal}

Muatan lokal adalah bahan kajian atau mata pelajaran pada satuan pendidikan yang berisi muatan dan proses pembelajaran tentang potensi dan keunikan lokal. ${ }^{4}$ Maksudnya adalah sebuah program pendidikan di sekolah dalam memberikan wawasan yang luas pada peserta didik tentang kekhususan yang ada di lingkungannya.

Tirtaraharjda dan La Sula, sebagaimana di kutip Iim Wasliman

2 Permendikbud, "Peraturan Menteri Pendidikan Dan Kebudayaan Republik Indonesia Nomor 81a Tahun 2013 Tentang Implementasi Kurikulum" (2013): hlm. 1.

3 Hamid Darmadi, Metode Penelitian Pendidikan Dan Sosial; Konsep Dasar Dan Implementasinya (Bandung: Alfabeta, 2013), hlm. 33.

4 Permendikbud, "Peraturan Menteri Pendidikan Dan Kebudayaan Nomor 79 Tahun 2014 Tentang Muatan Lokal Kurikulum 2013," Hlm. 2. 
Dewi Zainul Alfi dan M. Yunus Abu Bakar, Studi Kebijakan tentang Kurikulum

mengungkapkan bahwa kurikulum muatan lokal adalah “...suatu program pendidikan yang isi dan media dan strategi penyampaiannya dikaitkan dengan lingkungan alam, lingkungan sosial, dan lingkungan budaya serta kebutuhan daerah". ${ }^{5}$ Penulis menganggap kalau seperti ini berarti muatan lokal dijadikan sebagai pendekatan dalam penyampaian materi pembelajaran. Penyampaian materi yang dikaitkan dan menggunakan kondisi yang ada pada lingkungan tertentu.

Seperti yang disampaikan Nurdin Mansur, Guru haruslah dapat menyesuaikan materi pelajaran yang disampaikan disekolah dengan kenyataan yang dialami oleh peserta didik dalam masyarakat dimana dia berada. ${ }^{6}$ Dengan demikian dapat menambah wawasan murid tentang pengetahuan yang terintegrasi dengan lingkungannya, sumber daya alam, kondisi sosial, dan kebudayaan setempat.

Mulyasa dalam bukunya yang berjudul Implementasi Kurikulum Tingkat Satuan Pendidikan menyebutkan bahwa Kurikulum Muatan lokal adalah kegiatan kurikuler yang mengembangkan kompetensi yang disesuaikan dengan ciri khas dan potensi daerah, termasuk keunggulan daerah yang materinya tidak dapat dikelompokkan ke dalam mata pelajaran yang ada. Berarti muatan lokal akan berdiri sendiri diluar ruang lingkup mata pelajaran tertentu. Muatan lokal menjadi kegiatan tersendiri bagi peserta didik dalam penambahan kompetensi dan kemampuan diluar mata pelajaran formal.

Kebutuhan pengembangan wawasan mulok bagi peserta didik antar daerah berbeda-beda, namun secara garis besar memiliki tujuan yang hampir sama, yaitu: melestarikan dan mengembangkan kebudayaan daerah; dan meningkatkan kemampuan dan keterampilan di bidang tertentu, sesuai

\footnotetext{
${ }^{5}$ Muhammad Nasir, "Pengembangan Kurikulum Muatan Lokal Dalam Konteks Pendidikan Islam Di Madrasah," HUNAFA: Jurnal Studia Islamika 10, no. 1 (2013): hlm. 3.

${ }^{6}$ Nurdin Mansur, "Urgensi Kurikulum Muatan Lokal Dalam Pendidikan," Jurnal Ilmiah Didaktika 13, no. 1 (2012): hlm. 72.
} 
dengan potensi daerah masing-masing. ${ }^{7}$ Dengan begitu dalam proses pendidikan, peserta didik yang dihasilkan akan memiliki keunggulan masing-masing sesuai dengan satuan pendidikan tertentu.

Muatan lokal diorientasikan untuk menjembatani kebutuhan keluarga dan masyarakat dengan tujuan pendidikan nasional. Dapat pula dikemukakan, mata pelajaran ini juga memberikan peluang kepada siswa untuk mengembangkan kemampuannya yang dianggap perlu oleh daerah yang bersangkutan. Oleh sebab itu, mata pelajaran muatan lokal harus memuat karakteristik budaya lokal, keterampilan, nilai-nilai luhur budaya setempat dan mengangkat permasalahan sosial dan lingkungan yang pada akhirnya mampu membekali siswa dengan keterampilan dasar sebagai bekal dalam kehidupan.

\section{Tujuan Muatan Lokal}

Menurut Muhaimin, pengembangan kurikulum muatan lokal di Madrasah bertujuan mengembangkan potensi daerah sebagai bagian dari upaya peningkatan mutu pendidikan di Madrasah serta mengembangkan potensi Madrasah sehingga keunggulan kompetetif. ${ }^{8}$ Dengan kurikulum ini diharapkan, siswa di madrasah tidak tercerabut dari budaya, tradisi dan karakteristik masyarakat yang mengitarinya.

Pandangan Muhaimin di atas searah dengan penganut filsafat rekonstruksi sosial ${ }^{9}$ yang beranggapan bahwa kurikulum madrasah seharusnya memberi pengaruh terhadap reformasi masyarakat dan membantu mensyarakat untuk menjadi lebih baik. Ada tiga standar rekonstruksi social yang dikemukakan berdasarkan literature. Ketiga standar

7 Mursalim, "Kajian Pelaksanaan Pembelajaran Muatan Lokal Budaya Daerah Di Satuan Pendidikan Dasar ( a Study of Indigenous Culture in the Local Content Subject in Basic Education ) 1 ....," Kajian Pembelajaran Muatan Lokal Budaya Daerah di Satuan Pendidikan Dasar 10, no. 1 (2019): 2.

8 Muhaimin, Pengembangan Model Kurikulum Tingkat Satuan Pendidikan (KTSP) Di Sekolah Dan Madrasah, 1st ed. (Jakarta: PT. Raja Grafindo Persada, 2008), hlm. 94.

9 Uyoh Sadulloh, Pengantar Filsafat Pendidikan (Bandung: Alfabeta, 2007), hlm. 168. 
Dewi Zainul Alfi dan M. Yunus Abu Bakar, Studi Kebijakan tentang Kurikulum

ini memiliki tujuan yang berbeda yaitu;

a. Adaptasi sosial yang beranggapan bahwa kurikulum sekolah itu seharusnya menyesuaikan diri dengan kebutuhan masyarakat

b. Rekonstruksi social berarti adanya tuntutan untuk dilakukan perubahan kurikulum dengan melihat kepentingan masyarakat dan dilakukan sesegera mungkin dan

c. Perspektif masa depan yaitu pandangan yang speculative yang menganggap sekolah itu seperti bengkel untuk menemukan kebutuhan masyarakat.

Intinya adalah kurikulum sekolah dianggap sebagai wahana untuk perencanaan masa depan. Pendukung konsep ini menganggap bahwa isi atau materi kurikulum adalah hasil seleksi kebutuhan masyarakat, issu-issu social, ide-ide mutakhir dan aspirasi masa depan, isu-isu lingkungan, issu lingkungan, perdamaian dunia dan lain-lain.

Dapat pula dikemukakan, melalui penerapan kurikulum muatan lokal dapat memberikan bekal pengetahuan, keterampilan, pembentukan sikap dan perilaku siswa, berupa wawasan tentang keadaan lingkungan dan kebutuhan masyarakat. Dengan bekal tersebut diharapkan siswa mampu. mengembangkan serta melestarikan sumber daya alam dan kebudayaan yang ada di sekelilingnya.

Tujuan lain dari pemberian pengajaran muatan lokal adalah agar pengembangan sumber daya manusia yang terdapat di daerah setempat dapat dimanfaatkan untuk kepentingan pembangunan. Substansi kurikulum muatan lokal dapat ditentukan oleh satuan pendidikan yang tidak hanya terbatas pada mata pelajaran keterampilan, tetapi pembentukan sikap yang mencerminkan pengejewantahan nilai-nilai sosio-kulturla merupakan bagianpenting yang harus diberikan tempat dalam penerapankurikulum muatan lokal pada pendidikan formal. Secara lebih khusus, kurikulum muatan lokal bertujuan:

a. Mengenalkan dan mengakrabkan peserta didik dengan lingkungan 
alam, sosial, dan budayanya

b. Membekali peserta didik dengan kemampuan dan keterampilan serta pengetahuan mengenai daerahnya yang berguna bagi dirinya maupun lingkungan masyarakat pada umumnya

c. Memiliki sikap dan perilaku yang selaras dengan nilai-nilai atau aturan-aturan yang berlaku di daerahnya, serta melestarikan dan mengembangkan nilai-nilai luhur budaya setempat dalam rangka menunjang pembangunan nasional serta; d) menyadari lingkungan dan masalah-masalah yang ada di masyarakat serta dapat membantu mencari pemecahannya. ${ }^{10}$

\section{Landasan Kurikulum Muatan Lokal}

Pelaksanan kurikulum muatan lokal dalam konteks pendidikan Indonesia, relatif baru. Landasan yuridis pelaksanan kurikulum muatan lokal mengacu pada Surat Keputusan Menteri Pendidikan dan Kebudayaam Nomor 0412/U/1987. Sebagai penjabarannya tertuang dalam Keputusan Direktur Jendral Pendidikan Dasar Menenegah Nomor 173/-C/ Kep/M/1987.11 Dalam perkembangannya kemudian, keberadaan muatan lokal bertambah kuat dengan dijadikannya muatan lokal sebagai salah satu isi dan struktur kurikulum yang harus diberikan pada tingkat dasar dan menengah. Hal ini sebagaimana tercantum dalam Pasal 37 UU No. 20 Thn 2003 tentang Sistem Pendidikan Nasional, yang menyatakan bahwa Sekolah Dasar dan Menengah terdiri dari mata pelajaran pendidikan agama; pendidikan kewarganegaraan, bahasa; matematika; ilmu pengetahuan alam; Ilmu Pengetahuan Sosial; Seni dan Budaya; Pendidikan Jasmani dan Olahraga; Keterampilan/Kejuruan; dan muatan lokal (UU Sisdiknas No. 200 Th. 2003 Pasal 37 ayat 1).

\footnotetext{
${ }^{10}$ Muhaimin, Pengembangan Model Kurikulum Tingkat Satuan Pendidikan (KTSP) Di Sekolah Dan Madrasah, hlm. 94.

11 S. Dakir, Perencanaan Dan Pengembangan Kurikulum (Jakarta: Rhineka Cipta, 2004), hlm. 101.
} 
Dewi Zainul Alfi dan M. Yunus Abu Bakar, Studi Kebijakan tentang Kurikulum

Selanjutnya, dalam Peraturan Menteri Pendidikan Nasional (Permendiknas) No. 22 Tahun 2006 tentang standar isi menyatakan bahwa kurikulum Tingkat Satuan Pendidikan (KTSP) selain memuat beberapa mata pelajaran, juga terdapat mata pelajaran muatan lokal yang wajib diberikan pada semua tingkat satuan pendidikan. Kebijakan yang berkaitan dengan dimasukkannya mata pelajaran muatan lokal dalam standar isi dilandasi kenyataan bahwa Indonesia yang terdiri dari berbagai macam suku bangsa yang memiliki keanekaragaman multikultur (adat istiadat, tata cara, bahasa, kesenian, kerajinan, keterampilan daerah) merupakan ciri khas yang memperkaya nilai-nilai kehidupan bangsa Indonesia.

\section{Pelaksanaan Kurikulum Muatan Lokal}

Menurut sejarah, sebelum ada sekolah formal, pendidikan yang berprogram muatan lokal telah dilaksanakan oleh para orang tua peserta didik dengan metode drill dan dengan trial and error serta berdasarkan berbagai pengalaman yang mereka alami. Tujuannya yaitu agar mereka dapat mandiri dalam kehidupan. ${ }^{12}$ Pada statemen ini kita bisa mendapat gambaran sebenarnya muatan lokal dulu berjalan seperti apa, dan sekarang pun tampaknya tidak jauh berbeda.

Muatan lokal yang sekarang sudah formal diputuskan merupakan bagian dari struktur dan muatan kurikulum yang terdapat pada standar isi. Sesuai pada peraturan Menteri Pendidikan Nasional Nomor 22 tahun 2006 dicantumkan bahwa waktu untuk muatan lokal itu 2 jam pelajaran (2JP) dalam satu minggu. ${ }^{13}$ Keberadaan muatan lokal merupakan bentuk penyelenggaraan pendidikan yang tidak terpusat, sebagai upaya agar penyelenggaraan pendidikan di masing-masing daerah lebih meningkat relevansinya terhadap kebutuhan daerah yang bersangkutan. Penerapan

12 Achmad Basari, "Penguatan Kurikulum Muatan Lokal Dalam Pembelajaran Di Sekolah Dasar," Seminar Nasional Imu Pendidikan (2014): hlm. 19.

13 Permendiknas, "Peraturan Menteri Pendidikan Nasional Republik Indonesia Nomor 22 Tahun 2006 Tentang Standar Isi Untuk Satuan Pendidikan Dasar Dan Menengah” (2006): 1-48. 
kurikulum muatan lokal dapat memberikan bekal pengetahuan, keterampilan, pembentukan sikap dan perilaku siswa, berupa wawasan tentang keadaan lingkungan dan kebutuhan masyarakat. Dengan bekal tersebut diharapkan siswa mampu mengembangkan serta melestarikan sumber daya alam dan kebudayaan yang ada di sekelilingnya.

Dalam menjalankan muatan lokal, penentuan isi dan bahan pelajaran muatan lokal didasarkan pada kondisi lingkungan dapat berupa mata pelajaran yang berdiri sendiri. ${ }^{14}$ Sebagaimana pelajaran yang berdiri sendiri, maka muatan lokal juga memiliki alokasi waktu sendiri. Terkait materi, standart kompetensi dan kompetensi dasar untuk setiap jenis muatan lokal ditentukan oleh satuan pendidikan tersendiri.

Implementasi kebijakan pembelajaran muatan lokal budaya daerah di satuan pendidikan dasar perlu dianalisis agar terlihat output dan outcomenya bagi peningkatan kualitas pembelajaran mulok di daerah. ${ }^{15}$ Selain itu, proses pelaksanaan kebijakan tersebut harus diverifikasi dan dievaluasi agar diperoleh informasi terhadap aspek-aspek yang berpengaruh, serta menemukan alternatif solusi terhadap berbagai masalah. Dengan demikian, upaya ini dapat berkontribusi positif dalam aspek perencanaan, pelaksanaan, evaluasi, dan pencapaian tujuan.

Berdasarkan dengan yang ada dalam Permendikbud bahwa Satuan pendidikan (guru, kepala sekolah, komite sekolah/ madrasah) dalam mengembangkan materi/substansi/program muatan lokal yang sesuai dengan kebutuhan dan potensi di sekitarnya. ${ }^{16}$ Substansi Muatan lokal ditentukan oleh masing-masing satuan pendidikan. Pendapat ini tampaknya menganggap bahwa kurikulum muatan lokal hanya bisa diakomodasi melalui kegiatan yang terpisah dengan mata pelajaran.

14 Basari, "Penguatan Kurikulum Muatan Lokal Dalam Pembelajaran Di Sekolah Dasar," hlm. 19.

15 Mursalim, "Kajian Pembelajaran Muatan Lokal Budaya Daerah Di Satuan Pendidikan Dasar," Jurnal Puslitbang Kebudayaan 10, no. 1 (2015): hlm. 2.

16 PERMENDIKBUD, "Peraturan Menteri Pendidikan Dan Kebudayaan Republik Indonesia Nomor 81A Tahun 2013 Tentang Implementasi Kurikulum,” hlm. 2. 
Dewi Zainul Alfi dan M. Yunus Abu Bakar, Studi Kebijakan tentang Kurikulum

Dengan menggunakan lingkungan sebagai sumber belajar maka besar kemungkinan murid dapat mengamati, melakukan percobaan atau kegiatan belajar sendiri. Belajar mencari, mengolah, menemukan informasi sendiri dan menggunakan informasi untuk memecahkan masalah yang ada di lingkungannya merupakan pola dasar dari belajar.

\section{Pengembangan Kurikulum Muatan Lokal}

Untuk melangkah pada pengembangan tentunya memerlukan evaluasi terlebih dahulu untuk mengetahui hasil dari proses jalannya suatu program. Terkait muatan lokal, dalam Pasal 77P antara lain dinyatakan bahwa: ${ }^{17}$ (1) Pemerintah daerah provinsi melakukan koordinasi dan supervisi pengelolaan muatan lokal pada pendidikan menengah; (2) Pemerintah daerah kabupaten/kota melakukan koordinasi dan supervisi pengelolaan muatan lokal pada pendidikan dasar; (3) Pengelolaan muatan lokal meliputi penyiapan, penyusunan, dan evaluasi terhadap dokumen muatan lokal, buku teks pelajaran, dan buku panduan guru; dan (4) Dalam hal seluruh kabupaten/kota pada 1 (satu) provinsi sepakat menetapkan 1 (satu) muatan lokal yang sama, koordinasi dan supervisi pengelolaan kurikulum pada pendidikan dasar dilakukan oleh pemerintah daerah provinsi.

Pengembangan Muatan Lokal dilakukan dengan dua arah pengembangan dalam muatan lokal, yaitu Pengembangan untuk jangka jauh agar para siswa dapat melatih keahlian dan keterampilan yang sesuai dengan harapan yang nantinya dapat membantu dirinya, keluarga, masyarakat dan akhirnya membantu pembangunan nusa dan bangsanya. Oleh karena itu perkembangan muatan lokal dalam jangka panjang harus direncanakan secara sistematik oleh sekolah, keluarga, dan masyarakat setempat dengan perantara pakar-pakar pada instasi terkait baik negeri maupun swasta.

Pengembangan muatan lokal bisa dari segi subtansi. Yaitu mata

17 Ibid., hlm. 1. 
pelajaran muatan lokal ditentukan oleh satuan pendidikan, tidak terbatas pada mata pelajaran keterampilan. ${ }^{18}$ Ini menunjukkan bahwa satuan pendidikan memiliki kebebasan dalam memberikan muatan lokal pada peserta didik. Muatan lokal dapat dikembangkan sesuai kebutuhan dan perkembangan dilingkungan sekitar dengan sebaik mungkin.

Pengembangan Muatan Lokal berjalan pada beberapa prinsip yang terkandung dalam Permendikbud nomor 79 tahun 2014 yaitu:19

a. Kesesuaian dengan perkembangan peserta didik. tentunya sesuai dengan umur dan materi yang sesuai dengan kemampuan berfikirnya.

b. Keutuhan kompetensi.

c. Fleksibilitas jenis, bentuk, dan pengaturan waktu.

d. Kebermanfaatan untuk kepentingan nasional dan menghadapi tantangan global.

Pengembangan muatan lokal oleh satuan pendidikan dilakukan oleh tim pengembang kurikulum setempat yang juga melibatkan unsur komite sekolah serta pihak yang terlibat. Terkait tahapan pengembangan muatan lokal juga sudah dipaparkan dalam Permendikbud nomor 79 tahun 2014 yaitu sebagai berikut:

a. Analisis konten lingkungan alam, sosial, dan budaya. Identifikasi konteks ciri khas, potensi, keunggulan, kearifan lokal, dan kebutuhan/tuntutan daerah.

b. Identifikasi muatan lokal. Menentukan jenis muatan lokal yang akan dikembangkan.

c. Perumusan kompetensi dasar untuk setiap jenis muatan lokal. kesesuaian dengan tingkat perkembangan peserta didik.

d. Penentuan tingkat satuan pendidikan yang sesuai untuk setiap kompetensi dasar

18 Mansur Muslih, KTSP Pembelajaran Berbasis Kompetensi Dan Kontekstual, 7th ed. (Jakarta: Bumi Aksara, 2011), hlm. 30.

19 Permendikbud, "Peraturan Menteri Pendidikan Dan Kebudayaan Nomor 79 Tahun 2014 Tentang Muatan Lokal Kurikulum 2013," Hlm. 3. 
Dewi Zainul Alfi dan M. Yunus Abu Bakar, Studi Kebijakan tentang Kurikulum

e. Pengintegrasian kompetensi dasar ke dalam muatan pembelajaran yang relevan

f. Penetapan muatan lokal sebagai bagian dari muatan pembelajaran atau menjadi mata pelajaran yang berdiri sendiri

g. Penyusunan silabus; dan penyusunan buku teks pelajaran.

Sedangkan untuk melihat hasil dari pengembangan muatan lokal tersebut terdapat evaluasi yang dilakukan mencakup beberapa komponen yaitu sebagai berikut: ${ }^{20}$

a. Evaluasi program. Mencakup sarana dan dana yang diperlukan, dukungan pemerintah daerah dan masyarakat untuk menunjang pelaksanaan muatan lokal

b. Evaluasi Proses. Mencakup proses pembelajaran dilihat dari relevansi muatan lokal dengan kurikulum nasional, efesiensi dalam mencapai tujuan belajar

c. Evaluasi Produk. Mencakup hasil belajar peserta didik seperti perubahan sikap, dan keterampilan terkait materi muatan lokal, serta dampaknya terhadap lingkungan

\section{KESIMPULAN}

Muatan lokal adalah bahan kajian atau mata pelajaran pada satuan pendidikan yang berisi muatan dan proses pembelajaran tentang potensi dan keunikan lokal. Maksudnya adalah sebuah program pendidikan di sekolah dalam memberikan wawasan yang luas pada peserta didik tentang kekhususan yang ada di lingkungannya. Dalam menjalankan muatan lokal, penentuan isi dan bahan pelajaran muatan lokal didasarkan pada kondisi lingkungan dapat berupa mata pelajaran yang berdiri sendiri. Sebagaimana pelajaran yang berdiri sendiri, maka muatan lokal juga memiliki alokasi waktu sendiri. Terkait materi,

${ }^{20}$ Nana Sudjana, Pembinaan Dan Pengembangan Kurikulum Di Sekolah, IV. (Bandung: Sinar Baru Algensindo, 2002), hlm. 178. 
standart kompetensi dan kompetensi dasar untuk setiap jenis muatan lokal ditentukan oleh satuan pendidikan tersendiri.

Menurut Muhaimin, pengembangan kurikulum muatan lokal di Madrasah bertujuan mengembangkan potensi daerah sebagai bagian dari upaya peningkatan mutu pendidikan di Madrasah serta mengembangkan potensi Madrasah sehingga keunggulan kompetetif. Pengembangan muatan lokal oleh satuan pendidikan dilakukan oleh tim pengembang kurikulum setempat yang juga melibatkan unsur komite sekolah serta pihak yang terlibat. Terkait tahapan pengembangan muatan lokal juga sudah dipaparkan dalam Permendikbud nomor 79 tahun 2014 yaitu sebagai berikut; Analisis konten lingkungan, identifikasi muatan lokal, perumusan kompetensi dasar, penentuan materi, dan penyusunan silabus.

\section{DAFTAR PUSTAKA}

Basari, Achmad. "Penguatan Kurikulum Muatan Lokal Dalam Pembelajaran Di Sekolah Dasar." Seminar Nasional Imu Pendidikan (2014).

Dakir, S. Perencanaan Dan Pengembangan Kurikulum. Jakarta: Rhineka Cipta, 2004.

Mansur, Nurdin. “Urgensi Kurikulum Muatan Lokal Dalam Pendidikan.” Jurnal Ilmiah Didaktika 13, no. 1 (2012).

Muhaimin. Pengembangan Model Kurikulum Tingkat Satuan Pendidikan (KTSP) Di Sekolah Dan Madrasah. 1st ed. Jakarta: PT. Raja Grafindo Persada, 2008.

Mursalim. "Kajian Pelaksanaan Pembelajaran Muatan Lokal Budaya Daerah Di Satuan Pendidikan Dasar ( a Study of Indigenous Culture in the Local Content Subject in Basic Education ) 1 ...." Kajian Pembelajaran Muatan Lokal Budaya Daerah di Satuan Pendidikan Dasar 10, no. 1 (2019).

- - . "Kajian Pembelajaran Muatan Lokal Budaya Daerah Di Satuan Pendidikan Dasar." Jurnal Puslitbang Kebudayaan 10, no. 1 (2015).

Muslih, Mansur. KTSP Pembelajaran Berbasis Kompetensi Dan Kontekstual. 7th ed. Jakarta: Bumi Aksara, 2011.

Nasir, Muhammad. "Pengembangan Kurikulum Muatan Lokal Dalam Konteks Pendidikan Islam Di Madrasah." HUNAFA: Jurnal Studia Islamika 10, no. 1 (2013). 
Dewi Zainul Alfi dan M. Yunus Abu Bakar, Studi Kebijakan tentang Kurikulum

PERMENDIKBUD. "Peraturan Menteri Pendidikan Dan Kebudayaan Nomor 79

Tahun 2014 Tentang Muatan Lokal Kurikulum 2013” (2014). https://drive.google.com/file/d/0B-

Z3dLPaWpaqbk9FTThIYWM3bjQ/view.

- - - "Peraturan Menteri Pendidikan Dan Kebudayaan Republik Indonesia Nomor 81A Tahun 2013 Tentang Implementasi Kurikulum” (2013).

PERMENDIKNAS. "Peraturan Menteri Pendidikan Nasional Republik Indonesia Nomor 22 Tahun 2006 Tentang Standar Isi Untuk Satuan Pendidikan Dasar Dan Menengah" (2006).

Sadulloh, Uyoh. Pengantar Filsafat Pendidikan. Bandung: Alfabeta, 2007.

Sudjana, Nana. Pembinaan Dan Pengembangan Kurikulum Di Sekolah. IV. Bandung: Sinar Baru Algensindo, 2002. 